\title{
IUGS and the Global Change Program
}

According to the 1987 report of the World Resources Institute, "we are witnessing the birth of a sweeping new science. From it will come a powerful new understanding of the planet's structure and metabolism that could vastly improve the chances of sustaining billions more people." One of the more obvious signs of this interdisciplinary and global phenomenon, called by some Earth System Science, is the International Geosphere-Biosphere Program on Global Change, sponsored by the International Council of Scientific Unions. The IGBP Scientific Committee guiding the development of the program has now set up eight working groups to define the main areas for active study (see News report, this issue). Their emphasis is on the interactive biological, chemical, and physical processes that lead to changes in the global environment.

Within the geoscience community interest in the IGBP is growing rapidly, to judge by the increasing numbers of special symposia, workshops and public lectures at society and specialist meetings. There is keen interest to ensure that each current program, each discipline and subdiscipline is well represented in the new program. However, there is concern in some quarters that insufficient attention is being paid to input from the geosciences. As R.A. Price has put it, we hold the key to the "library of global change" that is stored in the rock and geomorphological record (see Episodes, June 1986, p. 91-94).
Accordingly, the Executive Committee of IUGS has just set up a Global Change Task Foree, initially headed by Prof. Ken Hsü of Switzerland, Chairman of the Union's Commission on Marine Geology. The charge to this task force is to recommend by this August a strategy for coordinating contributions from the geological sciences to the IGBP and, parenthetically, to ensure that the geosciences are not neglected. Meanwhile INQUA, the International Union for Quaternary Research (an IUGS affiliate), has already established a special committee under its former president, Hugues Faure of France, to emphasize the role of Quaternary studies in understanding and predicting global change.

The two other major umbrella associations that work in the earth sciences, IUGG (the International Union of Geodesy and Geophysics) and IGU (the International Geographical Union), have also set up special groups to link with the IGBP. And to ensure that the human dimension is not ignored, a parallel international program on Human Response to Global Change is being proposed by the International Federation of Institutes for Advanced Studies, the International Social Sciences Council and the United Nations University. It will be interesting to see what emerges from this veritable scramble and to track the development of what promises to be an international juggernaut in science. $\square$
LIST OF ABBREVIATIONS: Others are identified in the text or in the Directory of IUGS Bodies.

AGID

Association of Geoscientists for International Development

CODMUR IAGOD Commission on Ore Deporits in Mafic and Ultramafic Rocks

COGEODATA IUGS Committee on Storage, Automatic Processing, and Retrieval of Geological Data

DMP

DNPM

DTCD

FAO

GARS

GGT

GPS

GSGP

IAGOD

IASPEI

ICC

ICL

ICSU

IGBP

IGCP

IGU

ILP

INQUA

INHIGEO

IUGG

ODP

UNDP Deposit Modelling Program

Departamento Nacional da Producao Mineral United Nations Department of Technical Co-operation for Development UN Food and Agriculture Organization Geological Applications of Remote Sensing

Global Position Satellite

Global Sedimentary Geology Program

International Association on the Genesis of Ore Deposits

International Association of Seismology and Physies of the Earth's Interior

International Congress of Carboniferous Stratigraphy and Geology

Inter-Union Commission on the Lithosphere International Council of Scientific Unions International Geosphere-Biosphere Program International Geological Correlation Programme International Geographical Union International Lithosphere Program International Union for Quaternary Research International Committee on the History of Geological Sciences

International Union of Geodesy and Geophysics

Ocean Drilling Program

United Nations Development Programme Global Geoscience Transects

\section{FORTHCOMING ARTICLES}

Sea Level Changes

Metallogeny and Mineral Exploration

The Growth of Geology in South Korea

Stone Technology

The Cenozoic Development of the South China Sea Lithospheric Dynamics of China

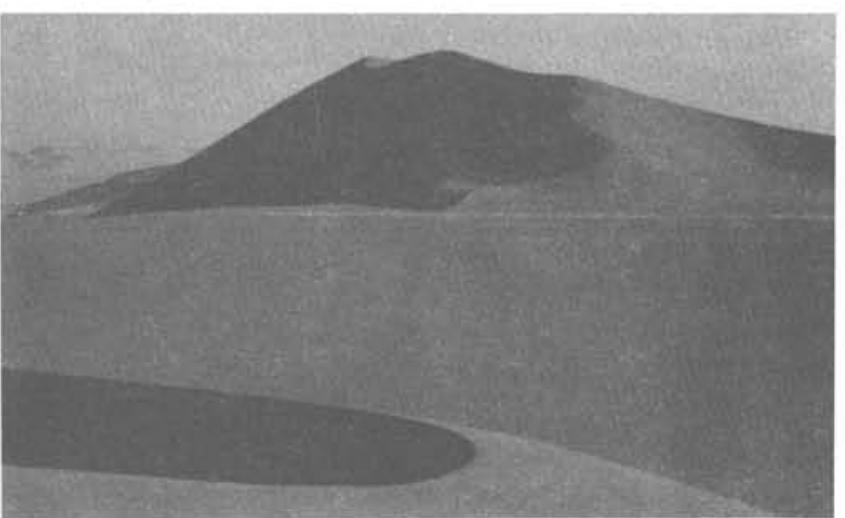

Cover Caption: Crest of a complex linear dune about $150 \mathrm{~m}$ high, Namib sand sea. See article by Lancaster, page 12. 